\title{
The role of effluent water irrigation in the mineral absorption of aerobic rice varieties (Oryza sativa L.)
}

\author{
Marks Ibadzade ${ }^{1,2}$ (1) $\cdot$ Ágnes Kun ${ }^{1} \cdot$ Árpád Székely ${ }^{1} \cdot$ Tímea Szalóki $^{1} \cdot$ Károly Penksza $^{2} \cdot$ Mihály Jancsó $^{1}$
}

Received: 22 October 2019 / Accepted: 12 November 2020 / Published online: 26 November 2020

(c) The Author(s) 2020

\begin{abstract}
Quality and quantity of different irrigation water types from conventional and alternative sources have a significant role on the productive parameters and chemical composition of crop plants. Appropriate alternative water sources and the reutilization of agricultural effluents can reduce the impact of rice production and animal husbandry on the natural water bodies. In the present study, influence of four different types of irrigation water was analyzed on the nutrient uptake $(\mathrm{P}, \mathrm{K}, \mathrm{Ca}, \mathrm{Mg}, \mathrm{Na})$ of aerobic rice (Oryza sativa L.) in a complex lysimeter experiment in two consecutive years. Early maturing Hungarian rice varieties (M 488 and Janka) were irrigated with traditional river water (RW) and different alternative irrigation sources to evaluate the feasibility of a sodium containing intensive fish farm effluent with (EWG) or without (EW) gypsum supplementation and with the addition of natural river water (EWGR). Significant effects on the mineral content of the aboveground biomass were measured. P uptake by M 488 and Janka decreased after the irrigation with EW in 2017. In case of EW, EWG and EWGR, the Na content increased significantly $(p \leq 0.05)$ in both varieties; however, pre-treatment of salt containing effluent waters can moderate the stress level. As a consequence, the ability of both rice varieties to absorb Na suggests that rice production could be conditionally part of bioremediation of salt-affected soils and water bodies.
\end{abstract}

Keywords Aerobic rice $\cdot$ Effluent water $\cdot$ Mineral content $\cdot$ Wastewater irrigation

\section{Introduction}

In the age of climate change and depletion of water resources, a new approach is needed to provide crops with sufficient water. It is especially important in climate vulnerable countries with arid and semi-arid areas, where growing plants suitable for these conditions is becoming an additional challenge for local farmers (Bortolini et al. 2018). Besides water-saving technologies, alternative sources of irrigation water, such as wastewaters or effluent waters, are among the opportunities that can help to cope with water scarcity (Tabatabaei et al. 2020).

Marks Ibadzade

marks.ibadzade@gmail.com

1 National Agricultural Research and Innovation Centre, Research Institute of Irrigation and Water Management, Anna Liget u. 35, H-5540 Szarvas, Hungary

2 Szent István University, Faculty of Agricultural and Environmental Sciences, Páter Károly u. 1, H-2100 Gödöllő, Hungary
The continuous increase of wastewater as a result of urbanization and industrial development has become a major option for agricultural use nowadays (Zakir et al. 2016). Moreover, agriculture itself also plays an indisputable role in freshwater pollution (Özerol et al. 2012; Hatfield 2015). Basically, large agricultural wastewater (AWW) discharges what come from poultry and livestock farming. Only for processing one bird with $2.3 \mathrm{~kg}$ on average $26.5 \mathrm{l}$ of water is required (Avula et al. 2009). According to Ran et al. (2016), livestock farming alone uses one-third of global agricultural water sources. In the end, usually AWW is discharged into soil or water bodies without treatment. Reuse of wastewater is becoming more and more important from the view of environmental protection, and on the other hand, it can also provide plants with the necessary macro- and microelements (Rahman et al. 2018). The biggest risk factor is that AWW often contains microbes and pathogens, chemicals, antibiotic residues and other substances that threaten the health of living organisms and nature (Yordanov 2010; Bustillo-Lecompte et al. 2016). However, nutrient-rich AWW, if properly treated in irrigated agriculture, can offer great benefits too (Domashenko and Vasilyev 2018; Villamar 
et al. 2018). Mekki et al. (2006) noted that wastewater from olive mills after pre-treatment positively affects soil structure and growth of several plants, such as tomato, wheat and beans. Singh et al. (2012) reported that application of wastewater containing high amount of nutrients greatly increased yield of different crops. Aquaculture is one of the main water-dependent sectors in agriculture, especially intensive aquaculture where large water volume and high protein content in feed are used. This results in a significant amount of nutrient-rich effluents (Kerepeczki et al. 2011). Management of the discharged wastewater from such systems still needs developments to lower the negative effects on natural water bodies (Csorbai and Urbányi 2019; Tóth et al. 2020.). There are traditional and improved methods for quality treatment that significantly determine the reutilization possibilities of output nutrients (Edwards 2015; Ribeiro and Naval 2019). However, aquaculture effluents that can be characterized by high sodium content need special pretreatments before conditionally reuse them in agricultural irrigation (Kun et al. 2018).

Rice (Oryza sativa L.) cultivation in many countries meets also water shortages and other environmental issues (He et al. 2016). This is really important because rice is a staple food for more than half of the world's population (Rejesus et al. 2012). According to the forecast of Seck et al. (2012), an additionally 116 million tons of rice production will be needed in order to provide the increasing demand by 2035 . Rice is not only a food crop, but also an important foundation for the economies of several developing countries (Van Dis et al. 2015). In India, according to Jena and Grote (2012), the total rice export in 2010-2011 was about 2.5 billion US dollars. Unfortunately, rice is one of the most water-intensive cereal crops among agricultural plants. Getting high yields is usually associated with many difficulties (water shortage, low temperature, diseases, etc.) due to its specific production technology (Stoop et al. 2009). Limited water resources and low farm income were reported as major limiting factors for rice farming (Nguyen and Ferrero 2006).

The aerobic rice system is one of the novel ways of intensive rice cultivation, where water consumption is many times reduced compared to the conventional paddy method (Bouman et al. 2002, 2005; Peng et al. 2006). Aerobic rice is grown mainly on non-saturated soils, while several irrigation techniques (e.g., alternative wetting, sprinkler irrigation, drip irrigation) can be applied. Thus, compared to the conventional paddy cultivation, it is easier to avoid water loss, but drought stress can occur more often. Moreover, other environmental stresses such as low temperature can also cause more serious damage in unfavorable seasons (Gombos and Simon-Kiss 2005). Under these circumstances, sufficient varieties and nutrient supply are required to maintain plant health and yield quality. In Hungary, new rice varieties with good abiotic stress tolerance such as Janka and Ábel were released via doubled haploid production (Pauk et al. 2009). These varieties were specially developed for the colder aerobic conditions of the temperate climate (Jancsó et al. 2017). The presence of various nutrients in AWW can even simplify the technology. For better understanding of agricultural and plant physiological processes, it is necessary to study rice grown under aerobic conditions with AWW irrigation and to evaluate its effect on the chemical composition of plants.

In the present study, Hungarian rice varieties were irrigated with traditional and alternative irrigation water in a complex lysimeter study to unravel the effects of fish farm effluents on the mineral composition of aerobic rice plants. This can lead us to the better understanding of the advantages and disadvantages of effluent irrigation. Moreover, deeper analysis of different alternative water sources and the reutilization of agricultural effluents can reduce the impact of rice production and animal husbandry on the natural water bodies and lead to better quality food and feed production too.

\section{Materials and methods}

\section{Experimental site and meteorological data}

The experiments were carried out in two consecutive years, 2017 and 2018, at the Lysimeter Station (Szarvas, Hungary) of the National Agricultural Research and Innovation Centre, Research Institute of Irrigation and Water Management (NAIK ÖVKI) (4651'48" N, 20³1'39" E). Two widespread Hungarian rice varieties "M 488" and "Janka" (both temperate japonicas) were chosen to test the effect of different irrigation water types on the mineral composition of aboveground biomass in aerobic rice.

Measurement of meteorological data was taken using meteorological equipment (Agromet-Solar automatic weather station, Boreas Ltd., Hungary) installed in the experimental field. Table 1 presents the monthly precipitation and temperature (average, minimum and maximum) over the years of the experiment.

\section{Experimental design and treatments}

Rice varieties were sown into 32 non-weighing backfilled gravitational lysimeters $\left(1 \mathrm{~m}^{3}\right)$ in 4 repetitions (Fig. 1). The bottom $10 \mathrm{~cm}$ of the lysimeters is a layer of fine gravel, and the upper $80 \mathrm{~cm}$ is a layer of soil; the soil type was vertisol (expansive clay). Gravitational lysimeters were chosen for the experiment mainly because of the isolation of the plants and soil from the horizontal and vertical environmental influences. Outflow of percolation water was not detected during the experiment. 
Table 1 Monthly precipitation and temperature (min., max., avg.) during growing seasons in 2017 and 2018

\begin{tabular}{|c|c|c|c|c|c|}
\hline \multirow[t]{2}{*}{ Year } & \multirow[t]{2}{*}{ Month } & \multirow{2}{*}{$\begin{array}{l}\text { Precipita- } \\
\text { tion }(\mathrm{mm})\end{array}$} & \multicolumn{3}{|c|}{ Temperature $\left({ }^{\circ} \mathrm{C}\right)$} \\
\hline & & & Minimum & Maximum & Average \\
\hline \multirow[t]{6}{*}{2017} & April & 49.7 & 0.0 & 25.0 & 11.0 \\
\hline & May & 40.9 & 4.2 & 30.5 & 17.2 \\
\hline & June & 69.3 & 10.5 & 33.3 & 22.1 \\
\hline & July & 31.8 & 11.0 & 36.4 & 22.8 \\
\hline & August & 33.3 & 8.2 & 39.2 & 23.7 \\
\hline & September & 74.2 & 5.4 & 34.3 & 16.6 \\
\hline \multirow[t]{6}{*}{2018} & April & 11.2 & 4.9 & 29.7 & 16.4 \\
\hline & May & 37.4 & 10.0 & 31.2 & 20.1 \\
\hline & June & 31.0 & 8.0 & 32.8 & 21.4 \\
\hline & July & 69.8 & 8.3 & 33.3 & 22.8 \\
\hline & August & 43.9 & 13.6 & 35.2 & 24.4 \\
\hline & September & 14.5 & 2.5 & 33.2 & 18.4 \\
\hline
\end{tabular}

In the course of the experiment, effect of four irrigation water types was investigated: raw effluent water (EW) from an intensive fish farm, effluent water supplemented with gypsum $(312 \mathrm{mg} / \mathrm{L}$ calcium sulfate) (EWG), effluent water diluted four times (1:3) with river water and supplemented with gypsum (EWGR) and natural river water (RW) as a control. The source of RW was a local oxbow lake of Körös River (4651'38.6" N 20³1'28.0" E, Szarvas, Hungary). Considering this, gypsum was addedto the EW according to the method proposed by Kun et al. (2018) in the EWG and EWGR irrigation. Thus, gypsum was applied in the EWG and EWGR to reduce the potential harmful effects of EW on the soil and plant development. Key indicators of water quality are listed in Table 2.

Microplots in the lysimeters were treated according to standard aerobic rice production technology. After direct dry
Table 2 The chemical parameters of irrigation water types used in the experiment

\begin{tabular}{lllll}
\hline & EW & EWG & EWGR & RW \\
\hline $\mathrm{pH}$ & 7.77 & 7.71 & 7.70 & 7.55 \\
Ammonium-N $\left(\mathrm{mg} / \mathrm{dm}^{3}\right)$ & 24.4 & 24.4 & 10.8 & 0.526 \\
Total phosphorus $\left(\mathrm{mg} / \mathrm{dm}^{3}\right)$ & 2.16 & 1.82 & 0.918 & 0.139 \\
Potassium $\left(\mathrm{mg} / \mathrm{dm}^{3}\right)$ & 6.25 & 6.34 & 5.40 & 3.93 \\
Calcium $\left(\mathrm{mg} / \mathrm{dm}^{3}\right)$ & 20.9 & 187.5 & 90.9 & 39.2 \\
Magnesium $\left(\mathrm{mg}^{3} / \mathrm{dm}^{3}\right)$ & 9.9 & 11.0 & 10.7 & 9.8 \\
Sodium $\left(\mathrm{mg} / \mathrm{dm}^{3}\right)$ & 276.3 & 266.8 & 131.3 & 35.3
\end{tabular}

$E W$ effluent water, $E W G$ effluent water supplemented with gypsum, $E W G R$ effluent water diluted with river water and supplemented with gypsum, $R W$ river water

sowing, pre-emergent herbicide (pendimethalin) was applied to suppress weed development. Later, during the growing season only mechanical weeding was used. Other plant protection interventions were not necessary. Commercially available micro-sprinkler irrigation system (Rivulis Rondo) with precision water meters was set up to the experimental site. Irrigation frequency and thus the gross irrigation amount per season were adjusted for weather conditions.

In the first year of the experiment, rice seeds were manually sowed on April 25, 2017. On June 13, $1 \mathrm{~kg}$ of fertilizer $\left(\mathrm{NH}_{4} \mathrm{NO}_{3}+\mathrm{CaMg}\left(\mathrm{CO}_{3}\right)_{2}\right)$ was applied $\left(84.4 \mathrm{~kg} \mathrm{~N} * \mathrm{ha}^{-1}\right)$. The irrigation water amount was $360 \mathrm{~mm}$. Plants were harvested on September 12, 2017.

In the second year of the experiment, rice seeds were manually sowed on April 25, 2018. Due to technological issues this year, it was not possible to fully utilize effluent water for irrigation, and fertilizer was not applied. The amount of irrigation water was only $60 \mathrm{~mm}$. However, the
Fig. 1 Experimental design in the lysimeter study. $E W$ effluent water, $E W G$ effluent water supplemented with gypsum, $E W G R$ effluent water diluted with river water and supplemented with gypsum, $R W$ river water (control). The numbers in the cells represent the identification number of the gravitational lysimeters. M 488, Janka-Hungarian rice varieties

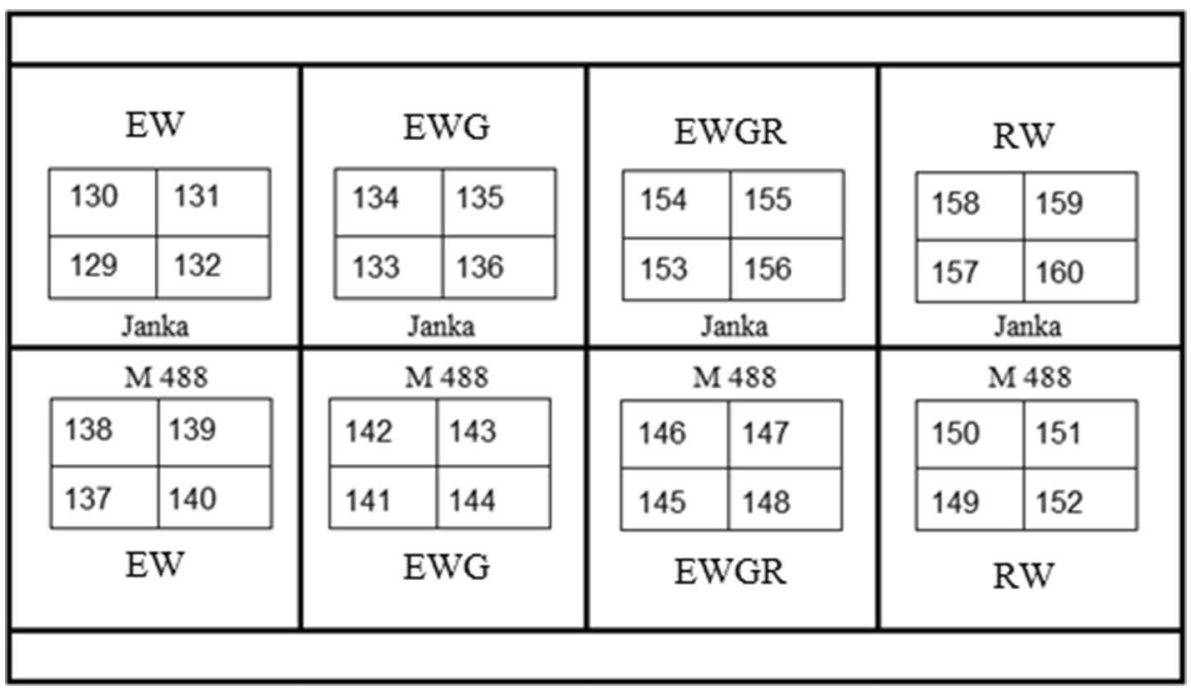


same irrigation scheme was applied as for the fore-crops, and therefore, a higher amount of sodium was measured in the soil of EW lysimeters (Table 3).

Harvesting was organized on August 22, 2018. After the harvest, whole aboveground parts of the rice plants were cut into small particles and after careful drying, samples were stored at room temperature.

\section{Laboratory analysis}

Effects of different irrigation water types on the chemical composition of rice varieties were analyzed at the NAIK ÖVKI Laboratory for Environmental Analytics (Szarvas, Hungary). After basic preparations (cleaning and drying), each sample was wet digested in $6 \mathrm{ml} \mathrm{HNO}_{3}$ and $2 \mathrm{ml} \mathrm{H}_{2} \mathrm{O}_{2}$ and after 1 day; the samples were kept in a microwave oven at a temperature of $180^{\circ} \mathrm{C}$ for $1.5 \mathrm{~h}$.

Calcium $(\mathrm{Ca})$, magnesium $(\mathrm{Mg})$, potassium $(\mathrm{K})$ and sodium $(\mathrm{Na})$ were measured with an atomic absorption spectrophotometer (Thermo Scientific Solaar M6, AAS). Phosphorous $(\mathrm{P})$ was determined by using inductively coupled plasma atomic emission spectroscopy (Thermo Scientific ICAP 6000 , ICP-OES). The determination of minerals was carried out in accordance with MSZ EN ISO 11885:2000 international and Hungarian standards.

\section{Statistical analysis}

Changes of the nutrient composition of plant samples were statistically analyzed in IBM SPSS 22 statistical environment. The collected data were subjected to the analysis of variance (ANOVA). The significant differences among irrigation treatments were determined with the Tukey test at $0.1 \%, 1 \%, 5 \%$ levels of probability, respectively.

\section{Results}

Statistical analysis of the combined data of varieties from 2017 (Table 4) shows that rice response varied markedly under different irrigation treatments. The Ca content of rice aboveground biomass was increased significantly $(p \leq 0.001)$ after EWG irrigation, similarly to the Mg content $(p \leq 0.05)$. While EW and EWG irrigation did not have a significant effect on these elements, although the $\mathrm{Mg}$ content was also higher after EW irrigation, the difference was statistically insignificant $(p=0.06)$. After EW and EWGR irrigation,

Table 3 The average $(n=4)$ chemical properties of soil in individual block lysimeters, 2018

\begin{tabular}{|c|c|c|c|c|c|c|c|c|}
\hline \multirow{2}{*}{$\begin{array}{l}\text { Lysimeters } \\
\text { Depth of the sample }(\mathrm{cm})\end{array}$} & \multicolumn{2}{|l|}{ EW } & \multicolumn{2}{|l|}{ EWG } & \multicolumn{2}{|l|}{ EWGR } & \multicolumn{2}{|l|}{ RW } \\
\hline & $0-45$ & $45-90$ & $0-45$ & $45-90$ & $0-45$ & $45-90$ & $0-45$ & $45-90$ \\
\hline $\mathrm{pH}(\mathrm{KCl})$ & 6.8 & 6.5 & 6.7 & 6.5 & 6.4 & 6.5 & 6.8 & 6.7 \\
\hline Phosphorus-pentoxide $\left(\mathrm{AL}-\mathrm{P}_{2} \mathrm{O}_{5}\right) \mathrm{m} / \mathrm{m} \%$ & 537.75 & 356.5 & 413 & 414.75 & 479 & 424.5 & 752.5 & 654.75 \\
\hline Potassium-oxide $\left(\mathrm{AL}-\mathrm{K}_{2} \mathrm{O}\right) \mathrm{m} / \mathrm{m} \%$ & 423.25 & 455.5 & 440 & 452 & 402.25 & 456.5 & 459.25 & 475.25 \\
\hline \multicolumn{9}{|l|}{ Exchangeable cations } \\
\hline $\mathrm{Na}\left(\mathrm{BaCl}_{2}\right) \mathrm{meq} / 100 \mathrm{~g}$ & 1.33 & 0.90 & 1.19 & 1.04 & 1.02 & 0.83 & 0.94 & 0.98 \\
\hline $\mathrm{K}\left(\mathrm{BaCl}_{2}\right) \mathrm{meq} / 100 \mathrm{~g}$ & 1.01 & 1.13 & 1.00 & 1.09 & 0.99 & 1.08 & 1.11 & 1.09 \\
\hline $\mathrm{Ca}\left(\mathrm{BaCl}_{2}\right) \mathrm{meq} / 100 \mathrm{~g}$ & 25.85 & 29.45 & 25.34 & 29.95 & 26.59 & 32.38 & 25.93 & 32.93 \\
\hline $\mathrm{Mg}\left(\mathrm{BaCl}_{2}\right) \mathrm{meq} / 100 \mathrm{~g}$ & 8.23 & 10.17 & 8.94 & 10.27 & 9.31 & 9.69 & 8.27 & 9.02 \\
\hline
\end{tabular}

$E W$ effluent water, $E W G$ effluent water supplemented with gypsum, $E W G R$ effluent water diluted with river water and supplemented with gypsum, $R W$ river water

Table 4 The average mineral content in aboveground biomass of rice, 2017

\begin{tabular}{llllll}
\hline Treatment & $\begin{array}{l}\mathrm{Ca} \\
(\mathrm{mg} / \mathrm{kg} \text { dry matter })\end{array}$ & $\begin{array}{l}\mathrm{Mg} \\
(\mathrm{mg} / \mathrm{kg} \\
\text { dry mat- } \\
\text { ter) }\end{array}$ & $\begin{array}{l}\mathrm{P} \\
(\mathrm{mg} / \mathrm{kg} \text { dry matter })\end{array}$ & $\begin{array}{l}\mathrm{K} \\
(\mathrm{mg} / \mathrm{kg} \\
\text { dry mat- } \\
\text { ter })\end{array}$ & $\begin{array}{l}\mathrm{Na} \\
(\mathrm{mg} / \mathrm{kg} \text { dry matter })\end{array}$ \\
\hline EW & 3938 & 2921 & $1538^{* * *}$ & 10691 & $1109 * * *$ \\
EWG & $4651^{* * *}$ & $2944^{*}$ & $1520^{* * *}$ & 10229 & $1013 * * *$ \\
EWGR & 3718 & 2679 & 1860 & 10789 & $607 * *$ \\
RW (control) & 3558 & 2644 & 2063 & 11567 & 383 \\
\hline
\end{tabular}

$E W$ effluent water, $E W G$ effluent water supplemented with gypsum, $E W G R$ effluent water diluted with river water and supplemented with gypsum, $R W$ river water

$*, * *, * * *$ - the mean difference is significant at the $0.05,0.01$ and 0.001 levels, respectively 
a significant $(p \leq 0.001)$ decrease in the $\mathrm{P}$ content was observed. At the same time, all the treatments had no significant $(p \geq 0.05)$ effect on the K content. Sodium was one of the main targets of the analysis, and after EW $(p \leq 0.001)$, EWG $(p \leq 0.001)$ and even EWGR $(p \leq 0.01)$ irrigation the $\mathrm{Na}$ content increased significantly.

In 2018, none of the treatments significantly ( $p \geq 0.05)$ affected the $\mathrm{Ca}, \mathrm{Mg}$ and $\mathrm{P}$ content of rice aboveground biomass (Table 5). After EW irrigation, the K content statistically $(p \leq 0.05)$ increased, but the other treatments did not cause significant $(p \geq 0.05)$ changes. As in the previous year, the Na content was statistically $(p \leq 0.001)$ higher in case of all effluent water containing treatments.

Analysis of individual varieties shows that $\mathrm{Ca}$ absorption of the M 488 rice variety increased after the irrigation with EW, EWG and EWGR in the first year (Table 6). Although we have observed a statistically significant difference only between EWG and RW $(p \leq 0.01)$, the average Ca content was $4967 \mathrm{mg} / \mathrm{kg}$ and $3527 \mathrm{mg} / \mathrm{kg}$ for EWG and RW irrigation, respectively. Neither the amount of $\mathrm{Mg}$, nor $\mathrm{K}$ in aboveground biomass of M 488 was statistically affected by treatments. However, a notable change was observed in case of $\mathrm{Mg}$ content after EWG irrigation $(3035 \mathrm{mg} / \mathrm{kg})(p=0.06)$ compared to the control. Despite the high amount of $\mathrm{P}$ in the effluent water, its application did not increase the level of $\mathrm{P}$ in aboveground biomass of $\mathrm{M} 488$. On the contrary, the $\mathrm{P}$ amount after EWGR irrigation was statistically similar to RW ( $p \geq 0.05$ ), but it was statistically lower after EW $(p \leq 0.05)$ and EWG $(p \leq 0.01)$ utilization. The average $\mathrm{P}$ was $1575 \mathrm{mg} / \mathrm{kg}, 1445 \mathrm{mg} / \mathrm{kg}, 1675 \mathrm{mg} / \mathrm{kg}$ and $2027 \mathrm{mg} / \mathrm{kg}$ for EW, EWG, EWGR and RW irrigation, respectively. Largest changes were recorded in case of $\mathrm{Na}$ content, where all effluent water containing treatments increased significantly the amount of $\mathrm{Na}$ in aboveground biomass of M 488. However, dilution and gypsum supplementation tend to decrease sodium accumulation. The average $\mathrm{Na}$ was $1155 \mathrm{mg} / \mathrm{kg}$, $1057 \mathrm{mg} / \mathrm{kg}, 685 \mathrm{mg} / \mathrm{kg}$ and $404 \mathrm{mg} / \mathrm{kg}$ for EW, EWG, EWGR and RW irrigation, respectively.

In the first year, the amount of $\mathrm{Ca}, \mathrm{Mg}, \mathrm{K}$ in aboveground biomass of Janka has changed as a result of $\mathrm{EW}$, EWG and EWGR irrigation (Table 7), but these changes were not statistically significant compared to the RW control $(p \geq 0.05)$. Similar to M 488, there was no increase in $\mathrm{P}$ content, although treatments contained higher levels of $\mathrm{P}$. The lowest $\mathrm{P}$ content was observed after EW irrigation, which was a statistically significant $(p \leq 0.01)$ difference compared to the control treatment. The average $P$ was $1500 \mathrm{mg} / \mathrm{kg}$ and $2097 \mathrm{mg} / \mathrm{kg}$ for EW and RW irrigation, respectively. Under the EWG irrigation, the P content in Janka was also lower, but there was no statistical $(p=0.07)$ difference. Opposite to M 488, the amount of $\mathrm{Na}$ after the EWGR irrigation in aboveground biomass of Janka gave statistically similar results with RW $(p \geq 0.05)$. But EW $(p \leq 0.001)$ and EWG $(p \leq 0.05)$ showed the same significant effects. The average
Table 5 The average mineral content in aboveground biomass of rice, 2018

Table 6 The average mineral content in aboveground biomass of M 488 rice variety, 2017

\begin{tabular}{lllllc}
\hline Treatment & $\begin{array}{l}\mathrm{Ca} \\
(\mathrm{mg} / \mathrm{kg} \text { dry } \\
\text { matter })\end{array}$ & $\begin{array}{l}\mathrm{Mg} \\
(\mathrm{mg} / \mathrm{kg} \text { dry } \\
\text { matter })\end{array}$ & $\begin{array}{l}\mathrm{P} \\
(\mathrm{mg} / \mathrm{kg} \text { dry } \\
\text { matter })\end{array}$ & $\begin{array}{l}\mathrm{K} \\
(\mathrm{mg} / \mathrm{kg} \text { dry matter })\end{array}$ & $\begin{array}{l}\mathrm{Na} \\
(\mathrm{mg} / \mathrm{kg} \text { dry matter })\end{array}$ \\
\hline EW & 2376 & 2327 & 2358 & $13725^{*}$ & $1029 * * *$ \\
EWG & 2580 & 2126 & 2285 & 11714 & $885^{* * *}$ \\
EWGR & 2618 & 2179 & 2159 & 11690 & $879^{* * *}$ \\
RW (control) & 2685 & 2176 & 2441 & 10910 & 370 \\
\hline
\end{tabular}

$E W$ effluent water, $E W G$ effluent water supplemented with gypsum, $E W G R$ effluent water diluted with river water and supplemented with gypsum, $R W$ river water

*,***-the mean difference is significant at the 0.05 and 0.001 levels, respectively

\begin{tabular}{lllllc}
\hline Treatment & $\begin{array}{l}\mathrm{Ca} \\
(\mathrm{mg} / \mathrm{kg} \text { dry matter })\end{array}$ & $\begin{array}{l}\mathrm{Mg} \\
(\mathrm{mg} / \mathrm{kg} \\
\text { dry mat- } \\
\text { ter })\end{array}$ & $\begin{array}{l}\mathrm{P} \\
(\mathrm{mg} / \mathrm{kg} \text { dry matter })\end{array}$ & $\begin{array}{l}\mathrm{K} \\
(\mathrm{mg} / \mathrm{kg} \\
\text { dry mat- } \\
\text { ter })\end{array}$ & $\begin{array}{l}\mathrm{Na} \\
(\mathrm{mg} / \mathrm{kg} \text { dry matter })\end{array}$ \\
\hline EW & 4092 & 2902 & $1575^{*}$ & 10795 & $1155^{* * *}$ \\
EWG & $4967^{* *}$ & 3035 & $1445^{* *}$ & 10180 & $1057^{* * *}$ \\
EWGR & 4055 & 2770 & 1675 & 10372 & $685^{* *}$ \\
RW (control) & 3527 & 2635 & 2027 & 10900 & 404 \\
\hline
\end{tabular}

$E W$ effluent water, $E W G$ effluent water supplemented with gypsum, $E W G R$ effluent water diluted with river water and supplemented with gypsum, $R W$ river water

$*^{* *},{ }^{* * *}$ - the mean difference is significant at the $0.05,0.01$ and 0.001 levels, respectively 
Na was $1062 \mathrm{mg} / \mathrm{kg}, 967 \mathrm{mg} / \mathrm{kg}, 528 \mathrm{mg} / \mathrm{kg}$ and $361 \mathrm{mg} /$ $\mathrm{kg}$ for EW, EWG, EWGR and RW irrigation, respectively.

In the second year (Table 8), the average amount of $\mathrm{Ca}$, $\mathrm{Mg}$ and $\mathrm{P}$ in aboveground biomass of $\mathrm{M} 488$ has remained stable; there was non-significant difference between treatments and control irrigation $(p \geq 0.05)$. However, non-significant differences were also found in case of $\mathrm{K}$ content after treatments, but EW irrigation resulted noticeable higher amounts than in control irrigation, 14057 and $11817 \mathrm{mg} /$ $\mathrm{kg}$, respectively. Like in the previous year, the percentage of $\mathrm{Na}$ in the aboveground biomass was increased due to the effluent water containing treatments. The differences were statistically significant compared to the control method $(p \leq 0.01)$. The average amount of Na at EW, EWG, EWGR and RW irrigation was $1006 \mathrm{mg} / \mathrm{kg}, 885 \mathrm{mg} / \mathrm{kg}, 982 \mathrm{mg} / \mathrm{kg}$ and $344 \mathrm{mg} / \mathrm{kg}$, respectively.

Similar results were also observed in the aboveground biomass of the Janka (Table 9), where the average content of $\mathrm{Ca}, \mathrm{Mg}$ and $\mathrm{P}$ remains statistically similar to the control after irrigation with EW, EWG and EWGR ( $p \geq 0.05)$. However, compared to the $\mathrm{M} 488$ rice variety, irrigation with EW increased the average content of $\mathrm{K}$, which was statistically significant $(p \leq 0.01)$ compared to EWGR and control irrigation. As in M 488, the average sodium content in Janka was also increased after the irrigation with EW, EWG and EWGR. The highest average Na content $(1051.5 \mathrm{mg} / \mathrm{kg}$ ) was measured after the EW irrigation. There was statistically significant difference between EW, EWG, EWGR and control
Table 7 The average mineral content in aboveground biomass of Janka rice variety, 2017

Table 8 The average mineral content in aboveground biomass of M 488 rice variety, 2018

\begin{tabular}{lllllc}
\hline Treatment & $\begin{array}{l}\mathrm{Ca} \\
(\mathrm{mg} / \mathrm{kg} \text { dry } \\
\text { matter })\end{array}$ & $\begin{array}{l}\mathrm{Mg} \\
(\mathrm{mg} / \mathrm{kg} \text { dry } \\
\text { matter })\end{array}$ & $\begin{array}{l}\mathrm{P} \\
(\mathrm{mg} / \mathrm{kg} \text { dry matter })\end{array}$ & $\begin{array}{l}\mathrm{K} \\
(\mathrm{mg} / \mathrm{kg} \text { dry } \\
\text { matter })\end{array}$ & $\begin{array}{l}\mathrm{Na} \\
(\mathrm{mg} / \mathrm{kg} \text { dry matter })\end{array}$ \\
\hline EW & 3782 & 2940 & $1500^{* *}$ & 10587 & $1062^{* * *}$ \\
EWG & 4335 & 2852 & 1595 & 10277 & $967^{*}$ \\
EWGR & 3380 & 2587 & 2045 & 11205 & 528 \\
RW (control) & 3587 & 2652 & 2097 & 11802 & 361 \\
\hline
\end{tabular}

$E W$ effluent water, $E W G$ effluent water supplemented with gypsum, $E W G R$ effluent water diluted with river water and supplemented with gypsum, $R W$ river water

$*^{* *},{ }^{* * *}$ - the mean difference is significant at the $0.05,0.01$ and 0.001 levels, respectively

\begin{tabular}{lllllc}
\hline Treatment & $\begin{array}{l}\mathrm{Ca} \\
(\mathrm{mg} / \mathrm{kg} \text { dry } \\
\text { matter })\end{array}$ & $\begin{array}{l}\mathrm{Mg} \\
(\mathrm{mg} / \mathrm{kg} \text { dry } \\
\text { matter })\end{array}$ & $\begin{array}{l}\text { P } \\
(\mathrm{mg} / \mathrm{kg} \text { dry } \\
\text { matter })\end{array}$ & $\begin{array}{l}\mathrm{K} \\
(\mathrm{mg} / \mathrm{kg} \text { dry } \\
\text { matter })\end{array}$ & $\begin{array}{l}\mathrm{Na} \\
(\mathrm{mg} / \mathrm{kg} \text { dry matter })\end{array}$ \\
\hline EW & 2455 & 2180 & 2242 & 14057 & $1006^{* *}$ \\
EWG & 2432 & 1890 & 2382 & 11892 & $885^{* *}$ \\
EWGR & 2825 & 2212 & 2100 & 13186 & $982^{* *}$ \\
RW (control) & 2655 & 2217 & 2605 & 11817 & 344 \\
\hline
\end{tabular}

$E W$ effluent water, $E W G$ effluent water supplemented with gypsum, $E W G R$ effluent water diluted with river water and supplemented with gypsum, $R W$ river water

** - the mean difference is significant at the 0.01 level

\begin{tabular}{lllllc}
\hline Treatment & $\begin{array}{l}\mathrm{Ca} \\
(\mathrm{mg} / \mathrm{kg} \text { dry } \\
\text { matter})\end{array}$ & $\begin{array}{l}\mathrm{Mg} \\
(\mathrm{mg} / \mathrm{kg} \text { dry } \\
\text { matter })\end{array}$ & $\begin{array}{l}\mathrm{P} \\
(\mathrm{mg} / \mathrm{kg} \text { dry } \\
\text { matter })\end{array}$ & $\begin{array}{l}\mathrm{K} \\
(\mathrm{mg} / \mathrm{kg} \text { dry matter })\end{array}$ & $\begin{array}{l}\mathrm{Na} \\
(\mathrm{mg} / \mathrm{kg} \text { dry matter })\end{array}$ \\
\hline EW & 2297 & 2437 & 2472 & $13392^{* *}$ & $1051^{* * *}$ \\
EWG & 2727 & 2362 & 2187 & 11535 & $884^{* * *}$ \\
EWGR & 2410 & 2145 & 2217 & 10567 & $776^{* *}$ \\
RW (control) & 2715 & 2135 & 2277 & 10002 & 395 \\
\hline
\end{tabular}

$E W$ effluent water, $E W G$ effluent water supplemented with gypsum, $E W G R$ effluent water diluted with river water and supplemented with gypsum, $R W$ river water

${ }^{* *},{ }^{* * *}$ - the mean difference is significant at the 0.01 and 0.001 levels, respectively 
irrigation. The average amount of $\mathrm{Na}$ at EWG, EWGR and RW irrigation was $884 \mathrm{mg} / \mathrm{kg}, 776 \mathrm{mg} / \mathrm{kg}$ and $395 \mathrm{mg} / \mathrm{kg}$, respectively.

\section{Discussion}

According to our initial assumption, comparative analysis of combined data from 2 years of studies suggests that both rice varieties were significantly influenced by the irrigation treatments, however not exactly in the same levels. The different results reflect the individual characteristics of rice varieties. The greatest role in this effect can be associated with the presence of $\mathrm{Na}$ in the effluent water from intensive fish farm. For the reduction of harmful effects of the EW on soil and plant development, in EWG and EWGR gypsum were also applied as it was developed by Kun et al. (2018).

As a consequence of EW irrigation, the average Na content increased after the first irrigation season (2017), while the average $\mathrm{P}$ content reduced in the above ground biomass of M 488. During irrigation with EWG, an increase in the average amount of $\mathrm{Ca}$ and $\mathrm{Na}$ and a decrease in $\mathrm{P}$ content were also observed. We have also found that $\mathrm{Na}$ increased the most among the analyzed elements as a result of EWGR in our study, while other elements remained stable. The effect of gypsum on higher Ca content was detected by means of EWG irrigation.

We have found some differences in case of the other temperate japonica rice variety, but as in M 488, EW irrigation caused increasing amount of $\mathrm{Na}$ in Janka too, and the average amount of $\mathrm{P}$ was also decreased. After the EWG irrigation only the Na content increased in case of Janka. But EWGR did not cause any changes in the amount of minerals after the first year.

In 2018, EW, EWG and EWGR irrigation increased the average amount of $\mathrm{Na}$ in both varieties. In Janka, EW also increased the amount of K. With EWG and EWGR, the other elements remained statistically similar.

According to El-Sharkawi et al. (2004), the mineral content of plants is closely related to the quality of water, and excessive salt content in water can reduce the uptake of minerals from the soil. In their experiment, Akter and Oue (2018) and Thu et al. (2017) also noted that a high $\mathrm{Na}^{+}$content can affect and decrease the absorption of several minerals as it creates a stressful environment for the plants, which was also observed in our experiment. Reduced absorption of P by M 488 and Janka was measured after effluent water application. But reducing stress conditions (e.g., EWG and EWGR) allows plants to make better utilize of minerals from water and soil. The application of limited irrigation in 2018 meant mild stress compared to the previous year, which ultimately did not have a considerable effect on the accumulation of minerals. However, the plants were exposed to the
$\mathrm{Na}$ accumulated in the soil as a result of previous year's irrigation, and the amount of $\mathrm{Na}$ in the aboveground biomass of both varieties increased.

Altogether, one of the main indicators of 2 years of experience was that the aboveground biomass of both types of varieties accumulate a large amount of $\mathrm{Na}$, influenced by environmental conditions and the amount of irrigation (treatments). The accumulation of $\mathrm{Na}$ in both genotypes is directly related to the fact that the $\mathrm{Na}$ transport mechanism is different from the transport mechanism of other $(\mathrm{Ca}, \mathrm{Mg}$, P, K) elements (Ochiai and Matoh 2002; Goel et al. 2011; Tanoi et al. 2011; Yang et al. 2014; Sasaki et al. 2016; Kant et al. 2018). Although the main goal of plants is to protect the seeds from the surplus of this toxic element, depending on the amount of sodium, it can be accumulated in the aboveground biomass (leaves, stems) (Marschner 1995; Reddy et al. 2017). At the same time, salinization can limit the uptake and accumulation of other important minerals (Hussain et al. 2017; Razzaq et al. 2020). We found that pre-treatment of salt containing effluent waters can moderate the stress effect of high sodium content in EW. However, further research is needed to find better irrigation water combinations.

Wastewater irrigation is a promising method that can provide plants sufficient water and essential nutrients, especially in arid and semi-arid regions. However, quality of the wastewater (e.g., total salt content, heavy metals) must be investigated frequently to avoid unnecessary damages in the agricultural and natural environments. In our experiment, in general, the assimilation of minerals by the plants was normal, but the presence of $\mathrm{Na}$ in the effluent water indicates that it can threaten the transformation and accumulation of minerals. On the other hand, the ability of both rice varieties to absorb Na suggests that rice production could be conditionally part of bioremediation of salt-affected soils and water bodies after further studies.

Acknowledgements The experiments were financially supported by O15500 and OD001 projects of the Hungarian Ministry of Agriculture. The research infrastructure was improved by GINOP-2.3.3-15-201600042 project. Marks Ibadzade is a scholarship holder of Stipendium Hungaricum.

Funding Open access funding provided by Szent István University.

Open Access This article is licensed under a Creative Commons Attribution 4.0 International License, which permits use, sharing, adaptation, distribution and reproduction in any medium or format, as long as you give appropriate credit to the original author(s) and the source, provide a link to the Creative Commons licence, and indicate if changes were made. The images or other third party material in this article are included in the article's Creative Commons licence, unless indicated otherwise in a credit line to the material. If material is not included in the article's Creative Commons licence and your intended use is not permitted by statutory regulation or exceeds the permitted use, you will 
need to obtain permission directly from the copyright holder. To view a copy of this licence, visit http://creativecommons.org/licenses/by/4.0/.

\section{References}

Akter M, Oue H (2018) Effect of saline irrigation on accumulation of $\mathrm{Na}^{+}, \mathrm{K}^{+}, \mathrm{Ca}^{2+}$, and $\mathrm{Mg}^{2+}$ ions in rice plants. Agriculture 8:164. https://doi.org/10.3390/agriculture8100164

Avula RY, Nelson HM, Singh RK (2009) Recycling of poultry process wastewater by ultrafiltration. Innov Food Sci Emerg Technol 10(1):1-8. https://doi.org/10.1016/j.ifset.2008.08.005

Bortolini L, Maucieri C, Borin M (2018) A tool for the evaluation of irrigation water quality in the arid and semi-arid regions. Agronomy 8(2):23. https://doi.org/10.3390/agronomy8020023

Bouman BAM, Wang H, Yang X, Zhao J, Wang C (2002) Aerobic rice (Han Dao): a new way of growing rice in water-short areas. In: Proceedings of the 12th inter-national soil conservation organization conference, Beijing, China. Tsinghua University Press, pp 175-181

Bouman BAM, Peng S, Castaneda AR, Visperas RM (2005) Yield and water use of irrigated tropical aerobic rice systems. Agric Water Manag 74(2):87-105. https://doi.org/10.1016/j.agwat .2004 .11 .007

Bustillo-Lecompte C, Mehrvar M, Quiñones-Bolaños E (2016) Slaughterhouse wastewater characterization and treatment: an economic and public health necessity of the meat processing industry in Ontario, Canada. J Geosci Environ Prot 4(4):175186. https://doi.org/10.4236/gep.2016.44021

Csorbai B, Urbányi B (2019) Investigations on the wastewater of a flow-through fish farming system. Columella 6(2):11-15. https ://doi.org/10.18380/szie.colum.2019.6.2.11

Domashenko Y, Vasilyev S (2018) Agroecological substantiation for the use of treated wastewater for irrigation of agricultural land. J Ecol Eng 19(1):48-54. https://doi.org/10.12911/22998 993/79567

Edwards P (2015) Aquaculture environment interactions: past, present and likely future trends. Aquaculture 447:2-14. https://doi. org/10.1016/j.aquaculture.2015.02.001

El-Sharkawi H, Irshad M, El-Serfy AM, Honna T, Hassan AKS, Mohamed T, Mahmoud E, Yamamoto S, Zahoor A (2004) Effect of water quality on grain yield and nutrient uptake of rice (Oryza sativa L.). Acta Agron Hung 52(2):141-148. https://doi. org/10.1556/aagr.52.2004.2.4

Goel A, Taj G, Pandey D, Gupta S, Kumar A (2011) Genome-wide comparative in silico analysis of calcium transporters of rice and sorghum. Genom Proteom Bioinf 9(4-5):138-150. https://doi. org/10.1016/s1672-0229(11)60017-x

Gombos B, Simon-Kiss I (2005) Bilinear thermal time models for predicting flowering time of rice. Cereal Res Commun 33(2-3):569579. https://doi.org/10.1556/crc.33.2005.2-3.121

Hatfield JL (2015) Environmental impact of water use in agriculture. Agron J 107(4):1554-1556. https://doi.org/10.2134/agron j14.0064

He HB, Yang R, Wu LQ, Jia B, Ma FY (2016) The growth characteristics and yield potential of rice (Oryza sativa) under non-flooded irrigation in arid region. Ann Appl Biol 168(3):337-356. https:// doi.org/10.1111/aab.12267

Hussain S, Zhang JH, Zhong C, Zhu LF, Cao XC, Yu SM, Jin QY (2017) Effects of salt stress on rice growth, development characteristics, and the regulating ways: a review. J Integr Agric 16(11):2357-2374. https://doi.org/10.1016/s2095-3119(16)61608 $-8$
Jancsó M, Székely Á, Szalóki T, Cs Lantos, Pauk J (2017) Performance of rice varieties under aerobic conditions in Hungary. Columella 4(1):83-88. https://doi.org/10.18380/szie.colum.2017.4.1.suppl

Jena PR, Grote U (2012) Impact evaluation of traditional Basmati rice cultivation in Uttarakhand State of Northern India: what implications does it hold for Geographical Indications? World Dev 40(9):1895-1907. https://doi.org/10.1016/j.worlddev.2012.04.004

Kant J, Ishizaki T, Pariasca-Tanaka J, Rose T, Wissuwa M, Watt M (2018) Phosphorus efficient phenotype of rice. Rice Crop Curr Dev. https://doi.org/10.5772/intechopen.75642

Kerepeczki É, Gál D, Kosáros T, Hegedús R, Gyalog G, Pekár F (2011) Natural water treatment method for intensive aquaculture effluent purification. Stud Univ Vasile Goldis Ser Stiint Vietii 21(4):827-837

Kun Á, Cs Bozán, Oncsik BM, Barta K (2018) Evaluating of wastewater irrigation in lysimeter experiment through energy willow yields and soil sodicity. Carpath J Earth Environ Sci 13(1):77-84. https://doi.org/10.26471/cjees/2018/013/008

Marschner H (1995) Diagnosis of deficiency and toxicity of mineral nutrients. Miner Nutr High Plants. https://doi.org/10.1016/b978012473542-2/50014-6

Mekki A, Dhouib A, Aloui F, Sayadi S (2006) Olive wastewater as an ecological fertiliser. Agron Sustain Dev 26:61-67. https://doi. org/10.1051/agro:2005061

Nguyen NV, Ferrero A (2006) Meeting the challenges of global rice production. Paddy Water Environ 4:1-9. https://doi.org/10.1007/ s10333-005-0031-5

Ochiai K, Matoh T (2002) Characterization of the $\mathrm{Na}+$ delivery from roots to shoots in rice under saline stress: excessive salt enhances apoplastic transport in rice plants. Soil Sci Plant Nutr 48(3):371378. https://doi.org/10.1080/00380768.2002.10409214

Özerol G, Bressers H, Coenen F (2012) Irrigated agriculture and environmental sustainability: an alignment perspective. Environ Sci Policy 23:57-67. https://doi.org/10.1016/j.envsci.2012.07.015

Pauk J, Jancsó M, Simon-Kiss I (2009) Rice doubled haploids and breeding. In: Touraev A, Forster BP, Jain SM (eds) Advances in haploid production in higher plants. Springer, Dordrecht. https:// doi.org/10.1007/978-1-4020-8854-4_16

Peng S, Bouman B, Visperas RM, Castañeda A, Nie L, Park HK (2006) Comparison between aerobic and flooded rice in the tropics: agronomic performance in an eight-season experiment. Field Crops Res 96(2-3):252-259. https://doi.org/10.1016/j.fcr.2005.07.007

Rahman MZ, Riesbeck F, Dupree S (2018) The opportunity versusrisks in wastewater irrigation. In: Hettiarachchi H, Ardakanian R (eds) Safe use of wastewater in agriculture. Springer, Cham, pp 13-25. http://doi-org-443.webvpn.fjmu.edu.cn/10.1007/978-3-319-74268 $-7 \_2$

Ran Y, Lannerstad M, Herrero M, Van Middelaar CE, De Boer IJ (2016) Assessing water resource use in livestock production: a review of methods. Livest Sci 187:68-79. https://doi. org/10.1016/j.livsci.2016.02.012

Razzaq A, Ali A, Safdar LB, Zafar MM, Rui Y, Shakeel A, Yuan Y (2020) Salt stress induces physiochemical alterations in rice grain composition and quality. J Food Sci 85(1):14-20. https:// doi.org/10.1111/1750-3841.14983

Reddy INBL, Kim BK, Yoon IS, Kim KH, Kwon TR (2017) Salt tolerance in rice: focus on mechanisms and approaches. Rice Sci 24(3):123-144. https://doi.org/10.1016/j.rsci.2016.09.004

Rejesus RM, Mohanty S, Balagtas JV (2012) Forecasting global rice consumption, Department of Agricultural and Resource Economics, North Carolina State University. Crit Rev Food Sci Nutr $57: 2455-2481$

Ribeiro FHM, Naval LP (2019) Reuse alternatives for effluents from the fish processing industry through multi-criteria analysis. J Clean Prod 227:336-345. https://doi.org/10.1016/j.jclepro.2019.04.110 
Sasaki A, Yamaji N, Ma JF (2016) Transporters involved in mineral nutrient uptake in rice. J Exp Bot 67(12):3645-3653. https://doi. org/10.1093/jxb/erw060

Seck PA, Diagne A, Mohanty S, Wopereis MC (2012) Crops that feed the world 7: rice. Food Secur 4(1):7-24. https://doi.org/10.1007/ s12571-012-0168-1

Singh PK, Deshbhratar PB, Ramteke DS (2012) Effects of sewage wastewater irrigation on soil properties, crop yield and environment. Agric Water Manag 103:100-104. https://doi.org/10.1016/j. agwat.2011.10.022

Stoop W, Adam A, Kassam AH (2009) Comparing rice production systems: a challenge for agronomic research and for the dissemination of knowledge intensive farming practices. Agric Water Manag 96:1491-1501. https://doi.org/10.1016/j.agwat.2009.06.022

Tabatabaei S, Nourmahnad N, Golestani Kermani S, Tabatabaei S, Najafi P, Heidarpour M (2020) Urban wastewater reuse in agriculture for irrigation in arid and semi-arid regions-a review. Int J Recycl Org Waste Agric 9(2):193-220. https://doi.org/10.30486 /ijrowa.2020.671672

Tanoi K, Saito T, Iwata N, Kobayashi NI, Nakanishi TM (2011) The analysis of magnesium transport system from external solution to xylem in rice root. Soil Sci Plant Nutr 57(2):265-271. https://doi. org/10.1080/00380768.2011.576397

Thu TTP, Yasui H, Yamakawa T (2017) Effects of salt stress on plant growth characteristics and mineral content in diverse rice genotypes. Soil Sci Plant Nutr 63:210-264

Tóth F, Zsuga K, Kerepeczki É, Berzi-Nagy L, Körmöczi L, Lövei LG (2020) Seasonal differences in taxonomic diversity of rotifer communities in a Hungarian Lowland Oxbow Lake exposed to aquaculture effluent. Water 12(5):1300. https://doi.org/10.3390/ w12051300

Van Dis R, Attwood S, Bogdanski A, DeClerck F, DeClerck R, Gemmill-Herren B, Hadi B, Horgan F, Rutsaert P, Turmel M-S, Garibaldi $L$ (2015) Counting the costs and benefits of rice farming. A trade-off analysis among different types of agricultural management. FAO, unpublished project report for The Economics of Ecosystems and Biodiversity (TEEB) global initiative for Agriculture and Food, p 64

Villamar CA, Vera-Puerto I, Rivera D, De la Hoz F (2018) Reuse and recycling of livestock and municipal wastewater in Chilean agriculture: a preliminary assessment. Water 10(6):817. https://doi. org/10.3390/w10060817

Yang T, Zhang S, Hu Y, Wu F, Hu Q, Chen G, Xu G (2014) The role of a potassium transporter OsHAK5 in potassium acquisition and transport from roots to shoots in rice at low potassium supply levels. Plant Physiol 166(2):945-959. https://doi.org/10.1104/ pp. 114.246520

Yordanov D (2010) Preliminary study of the efficiency of ultrafiltration treatment of poultry slaughterhouse wastewater. Bulg J Agric Sci 16(6):700-704

Zakir HM, Islam MM, Hossain MS (2016) Impact of urbanization and industrialization on irrigation water quality of a canal-a case study of Tongi canal, Bangladesh. Adv Environ Res 5(2):109-123. https ://doi.org/10.12989/aer.2016.5.2.109 